\title{
Microwave enhanced digestion of aerobic SBR sludge
}

\author{
Kevin J Kennedy*, Gabriel Thibault and Ronald L Droste \\ Department of Civil Engineering, University of Ottawa, Ottawa, ON, K1N 6N5, Canada
}

\begin{abstract}
Factorial experiments were carried out to determine the potential of microwaves (MWs) for improving characteristics of aerobic sequencing batch reactor (SBR) sludge to enhance mesophilic anaerobic digestion. Effects of pretreatment temperature, MW irradiation intensity and solids concentration on sludge characterisation parameters were monitored. Increasing pretreatment temperature in the 45 to $85^{\circ} \mathrm{C}$ range increased the soluble COD/total COD (chemical oxygen demand) ratio. MW intensity and sludge concentration in the 1 to $5 \%(\mathrm{w} / \mathrm{v})$ had minimal effects on solubilisation of COD. Biochemical methane potential (BMP) tests at $35^{\circ} \mathrm{C}$ used to investigate effects of MW temperature, number of MW cycles and partial SBR sludge pretreatment showed that partial MW pretreatment of sludge and increased MW exposure cycles does not significantly improve overall methane production. In general, BMP tests demonstrated that $100 \%$ of SBR sludge irradiated once to $85^{\circ} \mathrm{C}$ produced the greatest improvement in VS destruction (12\%) and overall methane production (16\%). Generally improved biogas production via MW pretreatment was not accompanied by any potential improvement in sludge dewaterability.
\end{abstract}

Keywords: anaerobic sludge digestion, microwave (MW), pretreatment, solubilisation, BMP

\section{Introduction}

Economically feasible treatment and disposal of municipal sludge is one of the most complex problems facing the environmental engineer (Droste, 1997). Primary sludge consists of settleable organic and inorganic matter and is readily degradable. Waste activated sludge (WAS) on the other hand consists of microbial biomass, extracellular polysaccharide substance (EPS) and inorganic material that is difficult to degrade due to the stability of the floc structure and microbial cell walls. (Eskicioglu et al.,2005). These two sludge types are typically mixed together and stabilised via anaerobic digestion (AD). As a large portion of the organic material is bound within the floc structure and cell walls in WAS, greater solids stabilisation and concomitant methane production may be obtained by pretreating WAS prior to digestion (Kim, 2003).

Pretreatment processes which aim to disrupt the WAS floc structure and bacterial cell walls in order to increase the organic material available for digestion include chemical (Woodard and Wukasch, 1994), electron beam (Shin and Kang, 2003), mechanical (Nah et al., 2000), ozonation (Weemaes et al., 2000; Yeom, 2002), thermal (Haug and Stuckey, 1978); ultrasound (Brown et al., 2003; Tiehm et al., 2001), steam explosion (Dereix et al., 2005) and combinations such as MICROSLUDGE (Stephenson et al., 2004) and CAMBI processes (Abraham and Kepp, 2003). Other potential advantages of pretreatment are significant reduction in pathogens and improved sludge dewaterability. While rate and extent of enhanced digestion varies with the type and extent of pretreatment there is a consensus that sludge pretreatment will eventually become the norm in treatment facilities. Mild thermal pretreatment at temperatures of less than $100^{\circ} \mathrm{C}$ (Gavala., 2003) has been reported to be particularly successful at improving both $\mathrm{AD}$ and reducing pathogens. An innovative

\footnotetext{
* To whom all correspondence should be addressed.

嘼 613-562 5800 ext. 6133; fax: 613-562-5873;

e-mail: kkennedy@uottawa.ca

Received 21 July 2006; accepted in revised form 8 January 2007.
}

thermal sludge pretreatment option is microwave (MW) irradiation. MW technology is capable of rapid and more uniform heating of polar molecules (such as water) while using less energy than conventional heating.

In small communities, wastewater treatment in complex plants which include primary and secondary treatment trains is not feasible and simpler processes such as the aerobic sequencing batch reactor (SBR) are used to treat screened and de-gritted wastewater at a long solids retention time (SRT). WAS accumulating during the settling phase is typically transferred to a drying pond then transported to a landfill for disposal. With implementation of the Kyoto Accord, small municipalities may be required to reduce $\mathrm{CO}_{2}$ emissions and recover the energy content of the sludge through $\mathrm{AD}$.

Hydrolysis, which involves enzymatic degradation of large and complex molecules into sugars, amino acids, and peptides is widely regarded as the rate-limiting step of WAS digestion (Palmowski and Muller, 2003). Depending on the pretreatment method, particle size reduction is typically accompanied by release of floc and cellular material due to cell rupture and modification of the cell/floc structure (Muller et al., 2004) enhancing hydrolysis. These mechanisms are responsible for improvements in the rate and/or extent of AD of pretreated sludge. Hong (2002) investigated use of MW irradiation to enhance AD of anaerobically digested, primary sludge and WAS (SRT not given) and to destroy pathogens. Heating to $70^{\circ} \mathrm{C}$, the soluble chemical oxygen demand/total chemical oxygen demand (sCOD/tCOD) ratio of the primary sludge increased slightly from 12 up to 13\% whereas the sCOD/tCOD ratio of the WAS increased from 8 up to $18 \%$. Primary sludge $\mathrm{MW}$ to 85 and $100^{\circ} \mathrm{C}$ resulted in 11.9 and $22.7 \%$ increases in biogas production, respectively while WAS irradiated to 85 and $100^{\circ} \mathrm{C}$ produced $11.4 \%$ and $15 \%$ improvements, respectively. Similarly, Park et al. (2004) demonstrated that MW irradiation of WAS (SRT not given) to $91^{\circ} \mathrm{C}$ increased sCOD/tCOD from 2 up to $19 \%$. Comparison of semi-continuous $\left(35^{\circ} \mathrm{C}\right) \mathrm{AD}$ control and pretreated sludge reactors at $10 \mathrm{~d}$ SRT showed a $36.6 \%$ improvement in biogas production with concomitant increase in volatile solids (VS) destruction from 23.2 up to $25.5 \%$. Eskicioglu et al. (2005) working with $3 \%$ (w/v) 
WAS (SRT of 4to $5 \mathrm{~d}$ ) reported MW irradiation to $96^{\circ} \mathrm{C}$ resulted in sCOD/tCOD increase from 5 to $20 \%$ and $17 \%$ improvement in overall biogas production, with similar improvement in VS destruction compared to controls. Zheng and Kennedy (2006) working with 3 to $4 \%$ total solids (TS) primary sludge reported MW irradiation to 65 and $90^{\circ} \mathrm{C}$ at various MW intensities resulted in a 2- to 3-fold increase of sCOD and a 15 to $30 \%$ improvement in the rate of biogas production but that ultimate degradability of primary sludge was unchanged. None of the MW pretreatment studies have applied to high SRT sludge or combined sludge from facilities without primary sedimentation. This research focuses on the effect of MW pretreatment on enhancing $\mathrm{AD}$ of combined sludge from an aerobic SBR with a long SRT. This study will use a combination of factorial experiments and biochemical methane potential (BMP) assays to determine the effects of MW pretreatment temperature, MW irradiation intensity, solids concentration as well as various MW heating strategies (multiple MW heat cycles, heat and hold temp) on improving characteristics of aerobic sequencing batch reactor (SBR) sludge to enhance mesophilic anaerobic digestion.

\section{Materials and methods}

\section{SBR sludge}

SBR sludge was obtained from the municipal wastewater treatment plant (MWTP) in Rockland, ON which incorporates coarse and fine screening, solids de-gritting followed by aerobic treatment and settling in an SBR. The SBR sequence is: fill $(2.67 \mathrm{~h})$, mix (3.33 h), settle $(1 \mathrm{~h})$ and decant $(1 \mathrm{~h})$ with an SRT of 12 to $14 \mathrm{~d}$ and food to micro-organism ratio of 0.24 . SBR sludge collected during the settling phase was approximately 1.5 to $3 \%$ TS.

\section{MW irradiation}

MW irradiation of SBR sludge was conducted in a household 1.460 W, $2.45 \mathrm{GHz}$ Panasonic MW oven (NN-S963) equipped with rotating platform and MW intensity control. Sludge was centrifuged to a concentration of $4.3 \%$ TS then diluted with distilled water to concentrations of between 1.5 and $4.0 \%$ TS as needed. Samples of $800 \mathrm{~m} \ell$ volume with varying TS concentrations were placed in a polypropylene container covered with plastic wrap to minimise evaporation, irradiated at an intensity of $100 \%$ for times between 45 and $270 \mathrm{~s}$ to achieve desired temperatures between 45 to $85^{\circ} \mathrm{C}$ (unless specified temperature hold-time was $0 \mathrm{~s}$ ). To evaluate effects of MW intensity, sludge concentration was kept constant at 3\% TS but MW intensity was varied between 60 and 100\% for times between 45 and $270 \mathrm{~s}$. Using the above methods, various SBR sludge concentrations were MW to various temperatures using differing MW intensities to evaluate the effect on enhanced mesophilic AD. Effects of multiple MW temperature cycles $(0,1,2,3)$ and effects of a 10 min MW temperature hold-time on sludge solubilisation and subsequent enhanced digestion were also tested. The effects of combining mildly alkaline pretreatment plus $\mathrm{MW}$ irradiation to $85^{\circ} \mathrm{C}$ vs. MW pretreatment to $85^{\circ} \mathrm{C}$ only on solubilisation and enhanced biogas production were also examined. Samples were cooled to $35^{\circ} \mathrm{C}$ for batch BMP tests.

\section{Anaerobic inoculum}

Anaerobic inoculum for BMP tests was MW acclimated in a $20 \ell$ semi-continuous reactor rotating at $50 \mathrm{r} / \mathrm{min}$ and kept at $35^{\circ} \mathrm{C}$. An SRT of $25 \mathrm{~d}$ was maintained by daily withdrawal of digested SBR sludge followed by addition of a 50:50 (v/v) mixture of irradiated (to $85^{\circ} \mathrm{C}$ ) and non-treated $2 \%$ TS SBR sludge. Acclimation of anaerobic seed was continued until daily biogas and biweekly tCOD, TS, VS, pH and volatile fatty acids (VFAs) stabilised which took two months. The acclimated inoculum had total VFAs of less than $25 \mathrm{mg} / \ell$.

\section{Ultimate SBR solubilisation}

An estimate of the maximum solubilisation of SBR sludge was determined by alkaline pretreatment (Tiehm et al., 2001). $\mathrm{NaOH}$ ( $2 \mathrm{~g} /$ bottle) was transferred to $16 \times 150 \mathrm{~m} \ell$ glass serum bottles to which $100 \mathrm{~m} \ell$ of well-mixed SBR sludge was added. Oxygen was removed by nitrogen sparging prior to the bottles being sealed with a butyl rubber stopper and placed on a shaker rotating at 50 $\mathrm{r} / \mathrm{min}$ in the dark at $22^{\circ} \mathrm{C}$. Controls and duplicate samples were reacted for $1,2,3,6,9,12,15$ and $24 \mathrm{~h}$ after which SCOD and tCOD tests were performed.

\section{BMP assay}

Batch BMP assays with controls were performed in duplicate on fully MW pretreated or partially MW pretreated SBR sludge volumes of $500 \mathrm{~m} \ell$ using $1 \ell$ Wheaton ${ }^{\circledR}$ borosilicate glass bottles (Speece, 1996). Sufficient alkalinity was ensured by adding $1 \mathrm{~g} / \ell$ of $\mathrm{NaHCO}_{3}$ and $\mathrm{KHCO}_{3}$ followed by $160 \mathrm{~m} \ell$ of acclimated anaerobic seed. Duplicate seed control bottles were also run with each test. Oxygen was removed by sparging the headspace with nitrogen gas prior to the bottles being closed with a butyl rubber stopper and capped. Bottles were placed in a darkened $35^{\circ} \mathrm{C}$ incubator shaker rotating at $30 \mathrm{r} / \mathrm{min}$. Biogas production was measured daily using water displacement with a manometer while biogas composition was determined 3 to 4 times during the BMP test. A portion of each sludge sample was used to measure alkalinity, ammonia, $\mathrm{pH}, \mathrm{sCOD}, \mathrm{tCOD}$, TS and VS and VFAs prior to the BMP assay for comparison to results at the end of the assay.

\section{Partial SBR sludge pretreatment BMP assays}

Barber (2002) reported the highest biogas yield and concomitant solids stabilisation occurred when partially pre-treating 50 to $60 \%$ of WAS with ultrasound, suggesting that full $100 \%$ WAS pretreatment produced inhibitory levels of certain unknown compounds. In the present experiment, the percent of SBR sludge MW pretreated was varied between 0 (control) and $100 \%$ and the temperature achieved by the MW treated fraction was varied between 45 and $85^{\circ} \mathrm{C}$ as shown in Table 4 . The SBR sludge had VS of $1.40 \pm 0.11 \%$ and tCOD was $22.921 \pm$ $932 \mathrm{mg} / \ell$. Additionally $\mathrm{NH}_{3}-\mathrm{N}$ concentration and alkalinity of all the samples ranged between 20 to $70 \mathrm{mg} / \ell$ and $2,190 \pm 110$ $\mathrm{mg} / \ell$ as $\mathrm{CaCO}_{3}$, respectively. VFA concentrations of pretreated SBR sludge samples were less than $130 \mathrm{mg} / \ell$ acetic acid and 100 $\mathrm{mg} / \ell$ propionic acid.

\section{MW/chemical, multi MW cycles and MW temperature hold time assays}

A second set of solubilisation tests and BMP assays was used to evaluate other MW pretreatment scenarios that might enhance anaerobic degradability of SBR sludge. One scenario was to combine MW pretreatment with mildly alkaline pretreatment $(\mathrm{NaOH})$. Because $\mathrm{NaOH}$ is expensive and its use requires subsequent neutralisation, a low dose (Lin et al., 1997) that would weaken cell membranes but not completely mask the effect obtained from MW irradiation on anaerobic biodegradability was evaluated. SBR sludge was dosed with $2 \mathrm{~g} / \mathrm{\ell} \mathrm{NaOH}$ for $12 \mathrm{~h}$ then neutralised with $6 \mathrm{~N} \mathrm{HCl}$ before MW heating (100\% intensity) to $85^{\circ} \mathrm{C}$. 
A second scenario investigated multiple MW irradiation cycles of SBR sludge to $85^{\circ} \mathrm{C}$. The number of irradiation cycles was varied between 0 and 3 both for $\mathrm{NaOH}$-treated and untreated SBR sludge. Sludge irradiated multiple times was cooled to room temperature in a $4^{\circ} \mathrm{C}$ freezer between irradiation cycles. The final test was to use the 'Keep Warm' feature of the MW oven at the end of a single irradiation cycle to hold the sludge at $85^{\circ} \mathrm{C}$ for ten minutes. Table 5 summarises the pretreatment conditions used for the second BMP assay.

At the beginning of the second BMP assay, $\mathrm{pH}$ was between 6.8 and 7.2; alkalinity ranged between 1400 to $2800 \mathrm{mg} / \ell$ as $\mathrm{CaCO}_{3}$ and VFA concentrations of all samples were less than $110 \mathrm{mg} / \ell$ acetic acid and $115 \mathrm{mg} / \ell$ propionic acid. Initial tCOD and VS of the samples were $16.460 \pm 564 \mathrm{mg} / \ell \mathrm{tCOD}$ and $1.04 \pm$ $0.06 \%$ VS which was about $72 \%$ of TS.

\section{Particle size distribution}

MW intensity effects on sludge particle size distribution were determined by sequential filtering of $500 \mathrm{~m} \ell$ samples using sieves with pore sizes of $100,60,30,11$ and $1 \mu \mathrm{m}$.

\section{Analytical methods}

Methane and $\mathrm{CO}_{2}$ content of the biogas were determined with a Hewlett-Packard 5710a gas chromatograph (GC), equipped with a thermal conductivity detector and a 3380A model integrator using the method described by Van Huyssteen (1967). The GC column was a Porepak T set $(6.35 \mathrm{~mm} \times 304.3 \mathrm{~cm})$ at $70^{\circ} \mathrm{C}$ with a helium gas carrier flow of $40 \mathrm{m \ell} / \mathrm{min}$. Biogas samples were taken from BMP bottles by means of an airtight syringe and $0.5 \mathrm{~m} \ell$ of biogas was injected into the $\mathrm{GC}$ for the determination.

VFAs were determined by an internal standard method described by Ackman (1972), using a Hewlett-Packard 5840A GC equipped with a flame ionisation detector, an auto sampler, a 5840 model integrator and a Chromosorb 101 packed column (304.8 cm x $2 \mathrm{~mm}$ ID, 80/100 mesh size). The oven temperature was $180^{\circ} \mathrm{C}$, the injector temperature was $250^{\circ} \mathrm{C}$ and the detector temperature was maintained at $350^{\circ} \mathrm{C}$. The flow rate of the formic acid saturated helium carrier gas was $15 \mathrm{m \ell} / \mathrm{min}$. Before injection $(10 \mu \ell)$ to the $\mathrm{GC}$, samples were centrifuged at 5000 $\mathrm{r} / \mathrm{min}$ for $5 \mathrm{~min}$ in a micro-centrifuge, and the supernatant was diluted with an equal volume of internal standard containing $1000 \mathrm{mg} / \ell$ isobutyric acid.

Total and volatile suspended solids determinations were based on procedures in Standard Methods (1998). Well-mixed samples were filtered through a pre-weighed GF/C fibreglass filter (VWR Can lab) and the residue retained on the filter was dried overnight to a constant weight in a $105^{\circ} \mathrm{C}$ oven. The increase in weight of the filter represented the TSS portion. The dried filter was ignited at $550^{\circ} \mathrm{C}$ in a muffle furnace for $20 \mathrm{~min}$. The difference between ash and dry weights represented the fixed fraction of the sample, and the difference between the TSS and the fixed fraction was considered to be the VSS portion.

Determination of COD used the colorimetric technique based on Procedure 5220D in Standards Methods (1998). sCOD determination necessitated centrifugation of samples at a relative centrifugal force (RCF) of 8 484g for 20 min followed by filtration of supernatant through Metricel $47 \mathrm{~mm}$ sterile 0.45 $\mu \mathrm{m}$ filters. All analyses were performed in duplicate. A PerkinElmer spectrophotometer was used to measure the absorbance at $600 \mathrm{~nm}$.

Standard Methods (1998) 2320B and 4500D were employed to measure alkalinity, and dissolved ammonia $\left(\mathrm{NH}_{3(\mathrm{aq})}\right.$ and $\left.\mathrm{NH}_{4}^{+}\right)$ respectively.

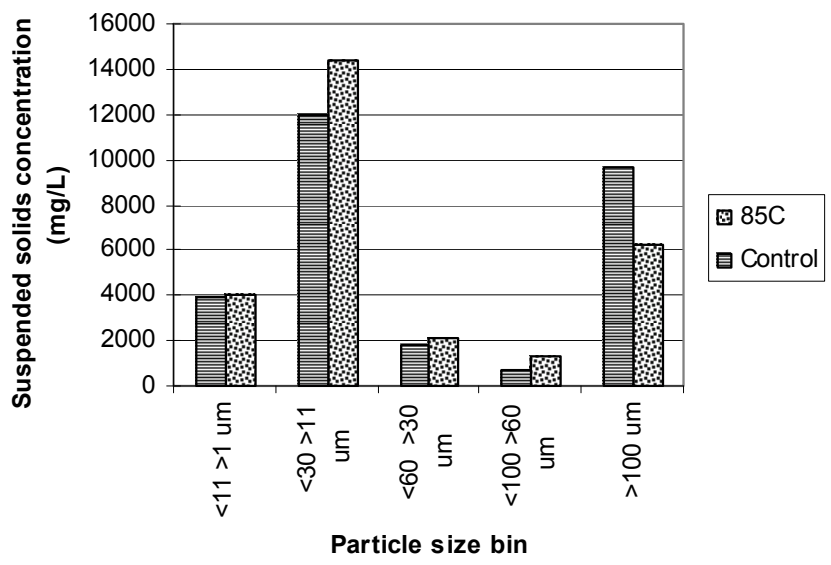

Figure 1

Particle size comparison of control and MW irradiated samples to $85^{\circ} \mathrm{C}$

Sludge dewaterability was determined using Standard Methods Procedure 2710G. Capillary suction time (CST) (in duplicate) of digested SBR sludge samples was determined using a Fann ${ }^{\circledR}$ capillary suction timer.

\section{Results and discussion}

\section{SBR sludge particle size distribution and solubilisation}

Effect of MW irradiation to $85^{\circ} \mathrm{C}$ at $100 \%$ MW intensity on SBR sludge particle size distribution shown in Fig. 1 shows that MW irradiated samples contain a smaller concentration of particles larger than $100 \mu \mathrm{m}$ and a re-distribution of particle sizes is observed in the smaller size bins. The increase in concentration of particles in the 11 to 30 and 60 to $100 \mu \mathrm{m}$ size ranges indicates that MW irradiation of SBR sludge is capable of breaking down large particles into smaller ones potentially increasing surface area available for biodegradation. Similar changes in particle sizes for the SBR sludge were not observed at lower MW pretreatment temperatures.

Prior to investigating effects of MW irradiation on solubilisation the maximum achievable COD solubilisation was estimated for a $1.40 \pm 0.11 \%$ volatile solids SBR sludge sample with tCOD of $22.921 \pm 932 \mathrm{mg} / \ell$. The $\operatorname{sCOD}(<0.45 \mu \mathrm{m}) / \mathrm{tCOD}$ ratios with time are shown in Fig. 2 (error bars represent standard deviation). The sCOD/tCOD ratio of untreated sludge was low (1.7\%), indicating that the COD is mainly exerted by particles larger than $0.45 \mu \mathrm{m}$. Alkaline solubilisation of sludge occurred rapidly. Within an hour sCOD/tCOD increased to $42.4 \%$ and after $24 \mathrm{~h}$ a maximum sCOD/tCOD ratio of $57 \%$ was achieved which was used for comparison with MW pretreatment.

A $2^{3}$ factorial experiment with central point was employed to investigate the impact of three MW factors on COD solubilisation $(y)$ and to compare the extent of solubilisation with the estimated maximum sCOD/tCOD ratio (57\%). A model resulting from this experiment could take the form below:

$$
\begin{aligned}
y= & \beta_{0}+\beta_{1} x_{1}+\beta_{2} x_{2}+\beta_{3} x_{3}+\beta_{4} x_{1} x_{2} \\
& +\beta_{5} x_{1} x_{3}+\beta_{6} x_{2} x_{3}+\beta_{7} x_{1} x_{2} x_{3}
\end{aligned}
$$

where:

$\beta$ symbols are constants

$x$ symbols are values of the three factors 


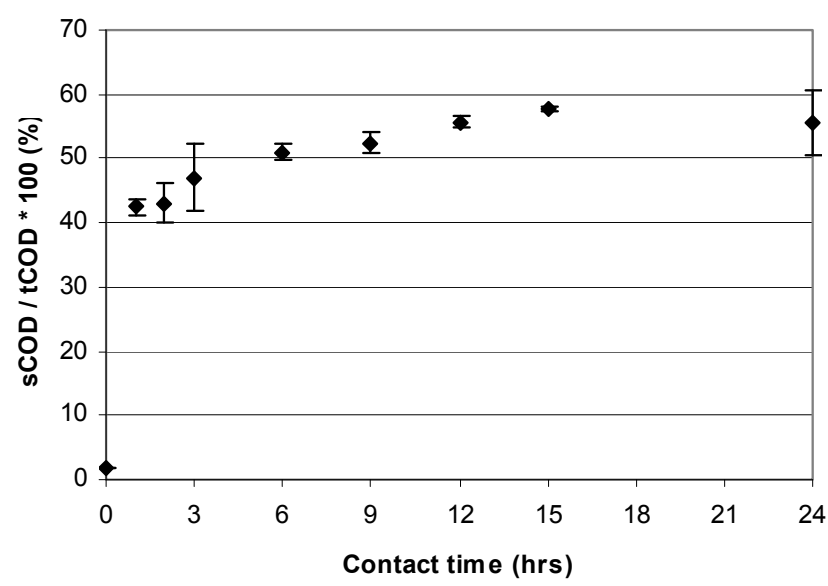

Figure 2

Estimation of maximum SCOD/tCOD ratio of SBR sludge using $\mathrm{NaOH}$ pretreatment

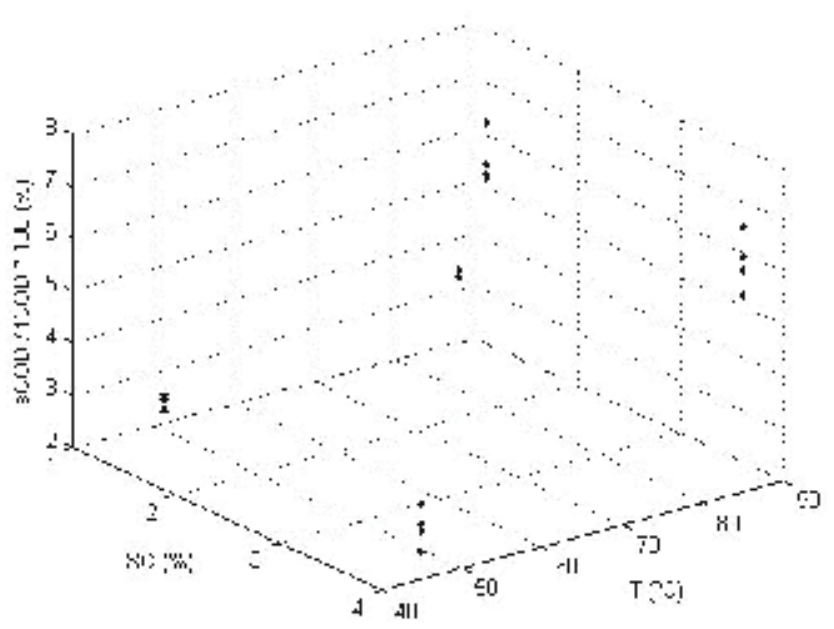

Figure 3

Effect of the temperature of MW pretreatment and SBR sludge concentration on COD solubilisation



Figure 4

Effect of the temperature of MW pretreatment and MW intensity on $C O D$ solubilisation
TABLE 1

SCOD/tCOD ratio of MW pretreated SBR sludge in the factorial experiment

\begin{tabular}{|l|c|c|c|c|}
\hline Run & $\begin{array}{c}\text { Tempera- } \\
\text { ture ( }\end{array}$ & $\begin{array}{c}\text { Sludge } \\
\text { concentra- } \\
\text { tion (\%) }\end{array}$ & $\begin{array}{c}\text { MW } \\
\text { intensity } \\
(\%)\end{array}$ & $\begin{array}{c}\text { sCOD/tCOD } \\
* \text { 100 (\%) }\end{array}$ \\
\hline 1A & 45 & 1.5 & 60 & 3.0 \\
\hline 1B & 45 & 1.5 & 60 & 3.3 \\
\hline 2A & 45 & 1.5 & 100 & 3.2 \\
\hline 2B & 45 & 1.5 & 100 & 2.9 \\
\hline 3A & 45 & 4.0 & 60 & 3.0 \\
\hline 3B & 45 & 4.0 & 60 & 3.1 \\
\hline 4A & 45 & 4.0 & 100 & 2.5 \\
\hline 4B & 45 & 4.0 & 100 & 3.4 \\
\hline 5A & 65 & 2.8 & 80 & 5.9 \\
\hline 5B & 65 & 2.8 & 80 & 6.0 \\
\hline 6A & 85 & 1.5 & 60 & 6.8 \\
\hline 6B & 85 & 1.5 & 60 & 6.0 \\
\hline 7A & 85 & 1.5 & 100 & 5.7 \\
\hline 7B & 85 & 1.5 & 100 & 5.8 \\
\hline 8A & 85 & 4.0 & 60 & 6.5 \\
\hline 8B & 85 & 4.0 & 60 & 7.1 \\
\hline 9A & 85 & 4.0 & 100 & 5.8 \\
\hline 9B & 85 & 4.0 & 100 & 6.2 \\
\hline Control A & - & 4.0 & - & 1.4 \\
\hline Control B & - & 2.8 & - & 1.3 \\
\hline Control C & - & 1.5 & - & 1.4 \\
\hline
\end{tabular}

The three factors studied were temperature reached by the sludge (T), MW irradiation intensity (MWI) and sludge concentration (SC) as shown in Table 1. It was deemed worthwhile to explore the MWI variable since for a specific temperature; sludge irradiated at $60 \%$ intensity would have a longer heat exposure time compared to samples irradiated at $100 \%$ intensity. Sludge concentration was also deemed of interest as it influences the quantity of polar solvent acting to heat the matrix.

The sCOD/tCOD ratio of control samples was approximately $1.4 \%$, which was similar to values in the alkaline solubilisation experiment. Increasing MW temperature attained by the sludge in the 45 to $85^{\circ} \mathrm{C}$ range had a positive effect on the solubilisation as the sCOD/tCOD ratio approximately doubled when sludge was heated to $45^{\circ} \mathrm{C}$ and reached approximately $6.8 \%$ for sludge treated to $85^{\circ} \mathrm{C}$ (Table 1) which represented about $12 \%$ of the maximum SBR sludge solubility. Plots of sCOD/tCOD ratio vs. temperature of MW pretreatment and sludge concentration are shown in Fig. 3 while Fig. 4 shows sCOD/tCOD ratio vs. the temperature of MW pretreatment and MW intensity. Visually, sludge concentration and MW intensity (in the range studied) do not appear to have a significant effect on the $\mathrm{SCOD} / \mathrm{tCOD}$ ratio. One goal of this experiment was to develop a relationship of the form shown in Eq. (1) between statistically significant factors and the sCOD/tCOD ratio achieved.

Results of the factorial experiment were analysed using the method of Berthouex and Brown (2002). The coded factorial matrix is shown in Table 2 where $X_{1}, X_{2}$ and $X_{3}$ represent the main factors T, MWI and SC, respectively, and $X_{12}, X_{13}, X_{23}$ and $X_{123}$ represent two and three-factor interactions. The last two columns show the average sCOD/tCOD ratio along with the standard deviation associated with duplicate irradiated samples. Results 
of the statistical analysis are presented in Table 3. Effects of primary factors and factor interactions were taken as significant if the $95 \%$ confidence interval of an effect did not contain zero.

Accordingly only temperature attained by MW sludge was found to significantly affect the sCOD/tCOD ratio and therefore, Eq. (1) can be simplified to describe the data. Because sludge concentration and MW intensity were shown to not significantly affect the sCOD/tCOD ratio, a linear equation relating temperature of MW pretreatment and SCOD/tCOD ratio is possible. However, the fit was poor and the linear model did not describe the plateau in sCOD/tCOD ratio when pretreatment temperature was above $65^{\circ} \mathrm{C}$. Consequently, Eq. (2) shown in Fig. 5 had a better distribution of residuals (not shown) and was better able to describe the results.

$$
y=-0.0032 x^{2}+0.4999 x-12.898\left(R^{2}=0.9498\right)
$$

where:

$$
\mathrm{x} \text { is temperature, }{ }^{\circ} \mathrm{C}
$$

Equation (2) is applicable to Rockland SBR sludge characterised by a SRT of about $14 \mathrm{~d}$, TS between 1.5 and $4.0 \%$ and heated to 45 to $85^{\circ} \mathrm{C}$ in a $1460 \mathrm{~W}$ MW? oven at intensities of between 60 and $100 \%$. The maximum sCOD/tCOD ratio obtained by MW irradiation was approximately $7 \%$ which was significantly lower than the maximum potential ratio of $57 \%$. The results indicate that $\mathrm{MW}$ irradiation to $85^{\circ} \mathrm{C}$ does not yield appreciable improvement in the solubilisation of COD over SBR sludge irradiated to $65^{\circ} \mathrm{C}$. While MW still has advantages such as high rate and focused heating and no chemical addition results suggest that higher temperatures may be needed to increase sludge solubilisation. The issue of the effect of MW pretreatment to enhance sludge stabilisation and biogas production was evaluated using mesophilic batch BMP assays.

\begin{tabular}{|c|c|c|c|c|c|c|c|c|c|c|}
\hline \multicolumn{10}{|c|}{ TABLE 2 } \\
\hline Run & $\mathbf{X}_{\mathbf{0}}$ & $\mathbf{X}_{1}$ & $\mathbf{X}_{\mathbf{2}}$ & $\mathbf{X}_{\mathbf{3}}$ & $\mathbf{x}_{\mathbf{1 2}}$ & $\mathbf{x}_{\mathbf{1 3}}$ & $\mathbf{x}_{\mathbf{2 3}}$ & $\mathbf{x}_{\mathbf{1 2 3}}$ & $\mathbf{y}$ & $\mathbf{s}^{\mathbf{2}}$ \\
\hline 1 & 1 & -1 & -1 & -1 & 1 & 1 & 1 & -1 & 3.15 & 0.03 \\
\hline 2 & 1 & -1 & -1 & 1 & 1 & -1 & -1 & 1 & 3.06 & 0.03 \\
\hline 3 & 1 & -1 & 1 & -1 & -1 & 1 & -1 & 1 & 3.02 & 0.01 \\
\hline 4 & 1 & -1 & 1 & 1 & -1 & -1 & 1 & -1 & 2.98 & 0.41 \\
\hline 5 & 1 & 1 & -1 & -1 & -1 & -1 & 1 & 1 & 6.39 & 0.30 \\
\hline 6 & 1 & 1 & -1 & 1 & -1 & 1 & -1 & -1 & 5.77 & 0.00 \\
\hline 7 & 1 & 1 & 1 & -1 & 1 & -1 & -1 & -1 & 6.79 & 0.16 \\
\hline 8 & 1 & 1 & 1 & 1 & 1 & 1 & 1 & 1 & 6.00 & 0.12 \\
\hline
\end{tabular}

The sCOD/tCOD ratios of MW pretreated SBR sludge prior to the BMP assays were checked and Eq. (3) $\left(T \rightarrow^{\circ} \mathrm{C}\right)$ which was very similar to Eq. (2) was found to exhibit the best fit to $\mathrm{sCOD/}$ tCOD ratios:

$$
\frac{s C O D}{t C O D} \times 100=-0.0032 T^{2}+0.50 T-12.9
$$

\section{BMP assays to determine MW effects on enhanced AD of SBR sludge: Partial MW pretreatment of SBR sludge}

The impact of partial MW SBR sludge pretreatment (100\% MW intensity) compared to complete MW pretreatment of the whole sample (100\% MW intensity) was determined via BMP assays. Cumulative biogas production of SBR sludge samples of which $20 \%$ was MW pretreated ( $80 \%$ not pretreated) to temperatures between 45 and $85^{\circ} \mathrm{C}$ was the first partial MW pretreatment examined. No lag phase or inhibition was exhibited by samples that were $20 \%$ pretreated as demonstrated by a rapid biogas production at the beginning of the BMP assay as well as the steady rate of biogas production for all samples (not shown). Additionally the ultimate quantity of biogas produced by all MW pretreated samples was approximately the same as that produced by the controls. MW pretreatment of only $20 \%$ of sludge samples to temperatures between 45 and $85^{\circ} \mathrm{C}$ did not improve or inhibit the rate of production or overall biogas production.

Biogas production from BMP assays containing 60\% MW pretreated SBR sludge and $40 \%$ untreated sludge is shown in

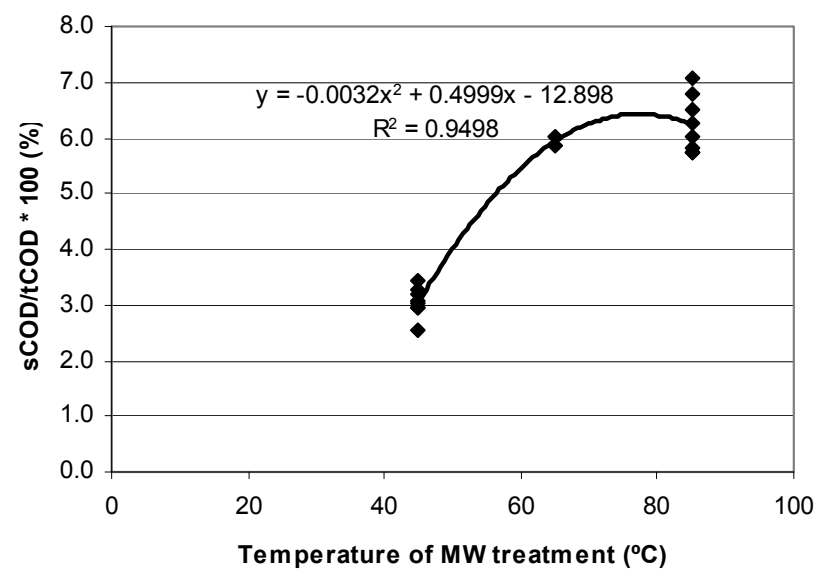

Figure 5

\begin{tabular}{|c|c|c|c|c|c|c|}
\hline \multicolumn{7}{|c|}{$\begin{array}{c}\text { TABLE } 3 \\
\text { Significance of primary factor and factor to factor interactions on SBR sludge solubilisation }\end{array}$} \\
\hline & Effect & $\begin{array}{l}\text { Variance } \\
\text { of effect }\end{array}$ & $\begin{array}{l}95 \% \text { confidence } \\
\text { interval }\end{array}$ & $\begin{array}{l}\text { Lower } \\
\text { boundary }\end{array}$ & $\begin{array}{l}\text { Upper } \\
\text { boundary }\end{array}$ & Significant \\
\hline $\mathrm{X}_{1}$ & 3.1850 & 0.0664 & 0.4123 & 2.7727 & 3.5973 & Yes \\
\hline $\mathrm{X}_{2}$ & 0.1050 & 0.0664 & 0.4123 & -0.3073 & 0.5173 & No \\
\hline $\mathrm{X}_{3}$ & -0.3850 & 0.0664 & 0.4123 & -0.7973 & 0.0273 & No \\
\hline Interaction of $X_{1}$ and $X_{2}$ & 0.2100 & 0.0664 & 0.4123 & -0.2023 & 0.6223 & No \\
\hline Interaction of $X_{1}$ and $X_{3}$ & -0.3200 & 0.0664 & 0.4123 & -0.7323 & 0.0923 & No \\
\hline Interaction of $X_{2}$ and $X_{3}$ & -0.0300 & 0.0664 & 0.4123 & -0.4423 & 0.3823 & No \\
\hline Interaction of $X_{1} X_{2} 1, X_{3}$ & -0.0550 & 0.0664 & 0.4123 & -0.4673 & 0.3573 & No \\
\hline
\end{tabular}

Second-order model relating temperature of $M W$ pretreatment and $S C O D / t C O D$ ratio (as percent). 


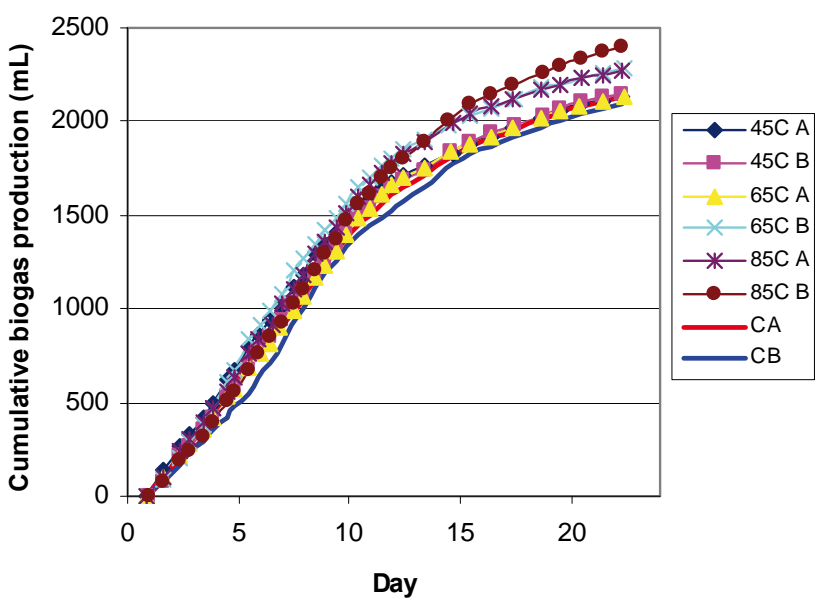

Figure 6

Biogas production from SBR sludge samples that were $60 \% \mathrm{MW}$ pretreated $40 \%$ no pretreatment

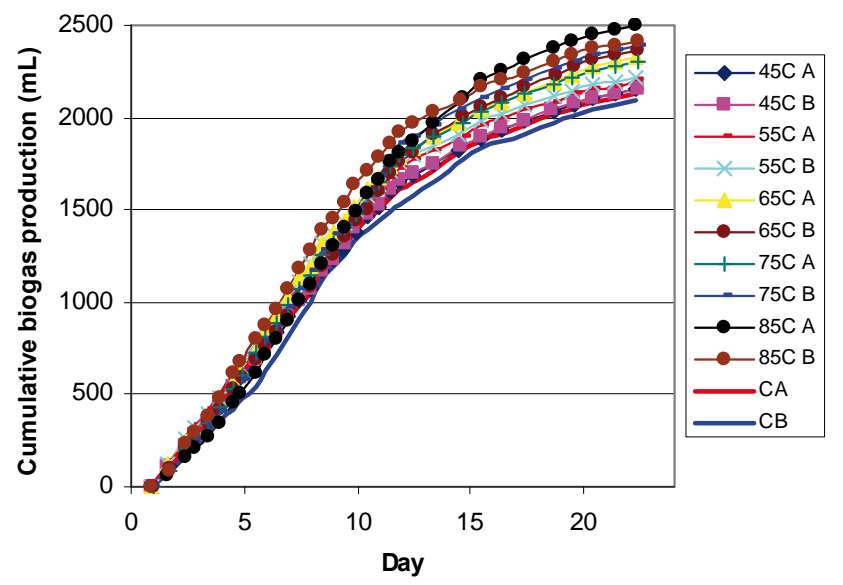

Figure 7

Biogas production from SBR sludge samples that were $100 \%$ $M W$ pretreated

Fig. 6. Again, no lag phase or evidence of inhibition was observed based on the rate of biogas production. However in this case, there was greater than $7 \%$ improvement in biogas production for the sludge mixture pretreated to $85^{\circ} \mathrm{C}(60 \% \mathrm{MW}$ pretreated SBR sludge and $40 \%$ untreated sludge) compared to the control (no pretreatment) suggesting no inhibition for 60\% partial MW pretreatment of sludge to $85^{\circ} \mathrm{C}$.

Biogas production from sludge samples that were 100\% pretreated with $\mathrm{MW}$ to temperatures between 45 and $85^{\circ} \mathrm{C}$ is shown in Fig. 7. Again, no lag phase or evidence of inhibition was observed. Pretreatment of sludge samples to temperatures less than $65^{\circ} \mathrm{C}$ did not result in conclusive improvements in overall biogas production. However, pretreatment to 65,75 and $85^{\circ} \mathrm{C}$ resulted in 10.8, 10.9 and $16.2 \%$ improvements, respectively, in overall biogas production compared to the control (no MW pretreatment). Hence, despite similar solubilisation of COD at MW irradiation temperatures of 65 and $85^{\circ} \mathrm{C}$, samples heated to $85^{\circ} \mathrm{C}$ produced more biogas than those heated to 65 and $75^{\circ} \mathrm{C}$. This may be hypothesised to be due to a more successful disruption of floc particles larger than $100 \mu \mathrm{m}$ into particles larger than 0.45 $\mu \mathrm{m}$ at a temperature of $85^{\circ} \mathrm{C}$ than at 65 and $75^{\circ} \mathrm{C}$ resulting in more organic matter being available for anaerobic degradation. It can be observed in Fig. 7 that all samples were characterised by an initial constant biogas production rate of approximately
$150 \mathrm{~m} \ell / \mathrm{d}$. The difference between the best pretreatment conditions and the control was the duration of this maximum biogas production rate. MW pretreatment of $100 \%$ of the SBR sludge to $85^{\circ} \mathrm{C}$ resulted in no inhibition and the rate of digestion was similar for controls, full and partial MW pretreatment. However, the greatest improvement for the extent of SBR sludge degradation occurred with $100 \%$ of the SBR sludge under went MW pretreatment. Hence, pretreatment of this particular SBR sludge by MW irradiation does not affect the rate of degradation but enhances substrate degradability. These results are in contrast with those of Barber (2002) which showed advantages for partial ultrasound sludge pretreatment over full pretreatment. It is possible that there are differences in ultrasound and MW pretreatment or that the use of MW-acclimated inoculum negated any inhibitory effect that might appear with unacclimated inoculum. Barber (2002) did not indicate if ultrasound-acclimated inoculum was used.

The composition of biogas in all BMP tests was 70 to $75 \%$ $\mathrm{CH}_{4}$ and 25 to $30 \% \mathrm{CO}_{2}$. The $\mathrm{pH}$ at the conclusion of the test was approximately 7.2 for all pretreated and control samples while alkalinity ranged between 3200 and $4100 \mathrm{mg} / \ell$ as $\mathrm{CaCO}_{3}$. All these values are well within the range for good digestion. Additionally sCOD of all samples after $25 \mathrm{~d}$ ranged between 255 to $455 \mathrm{mg} / \ell$ indicating that a portion of the organic matter solubilised during MW pretreatment or produced during digestion was recalcitrant to anaerobic degradation. Ammonia-N concentrations in all samples at the end of the BMP assay were in the 325 to $520 \mathrm{mg} / \ell$ range with the higher concentrations associated with high MW pretreatment temperatures. These samples had the highest biogas production and greatest destruction of VS and nitrogen-rich organic matter. Ammonia concentrations were not in the inhibitory range (Speece, 1996).

Table 4 shows that the average VS removal in the control samples was $49 \%$ and increased to $56 \%$ for samples that were fully MW pretreated to $85^{\circ} \mathrm{C}$. This result concurs with tCOD removals (not discussed) and cumulative biogas data providing further confidence in the improvement in the extent of digestion of SBR sludge pretreated with MW irradiation. Post-digested SBR sludge dewaterability results were inconclusive with slightly higher CSTs indicating that no potential improvement in SBR sludge dewaterability with MW pretreatment is likely. This is in contrast to MW pretreatment studies with secondary WAS (5 d SRT) only that indicated potential improvements in sludge dewaterability. It is possible that the mix of primary and WAS in SBR sludge or the longer SRT of the SBR sludge may account for this difference.

\section{MW/chemical, multi MW cycles and MW temperature hold time assays}

Positive results for MW sludge pretreatment obtained in the partial MW pretreatment BMP assay led to evaluation of other pretreatment variables that might further enhance anaerobic degradability of SBR sludge. Combined MW pretreatment with mildly alkaline pretreatment, multiple MW irradiation cycles and a single irradiation cycle followed by a $10 \mathrm{~min}$ hold at $85^{\circ} \mathrm{C}$. Table 5 summarises the pretreatment conditions used as well as the COD removal efficiencies and methane yields for the BMP assays.

The sCOD/tCOD ratios of untreated and $\mathrm{NaOH}$-treated sludge irradiated 0, 1, 2 and 3 times are shown in Fig. 8. sCOD/ tCOD ratio of the control was $2.06 \pm 0.03 \%$ which is slightly higher than the $1.72 \pm 0.04 \%$ obtained in the first BMP assay and illustrates temporal variability of the SBR sludge source. The 


\begin{tabular}{|c|c|c|c|}
\hline \multicolumn{4}{|c|}{$\begin{array}{c}\text { TABLE 4 } \\
\text { Experimental conditions and effect of MW } \\
\text { pretreatment temperature and proportion of sludge } \\
\text { pretreated on VS removal in first BMP assay }\end{array}$} \\
\hline Sample & $\begin{array}{l}\text { Pretreatment } \\
\text { conditions }(\% \text { of } \\
\text { sample } \mathrm{MW} \text { pre- } \\
\left.\text { treated } /{ }^{\circ} \mathrm{C}\right) \\
\end{array}$ & VS removal (\%) & $\begin{array}{c}\text { Average } \\
\text { VS removal } \\
(\%)\end{array}$ \\
\hline $1 \mathrm{~A}$ & \multirow{2}{*}{$20 / 45$} & 48 & \multirow{2}{*}{50} \\
\hline $1 \mathrm{~B}$ & & 52 & \\
\hline $2 \mathrm{~A}$ & \multirow{2}{*}{$20 / 65$} & 45 & \multirow{2}{*}{49} \\
\hline $2 B$ & & 53 & \\
\hline $3 \mathrm{~A}$ & \multirow{2}{*}{$20 / 85$} & 53 & \multirow{2}{*}{51} \\
\hline $3 \mathrm{~B}$ & & 49 & \\
\hline $4 \mathrm{~A}$ & \multirow{2}{*}{$60 / 45$} & 50 & \multirow{2}{*}{50} \\
\hline $4 \mathrm{~B}$ & & 50 & \\
\hline $5 \mathrm{~A}$ & \multirow{2}{*}{ 60/65 } & 54 & \multirow{2}{*}{52} \\
\hline $5 B$ & & 50 & \\
\hline $6 \mathrm{~A}$ & \multirow{2}{*}{ 60/85 } & 51 & \multirow{2}{*}{51} \\
\hline $6 \mathrm{~B}$ & & 51 & \\
\hline $7 \mathrm{~A}$ & \multirow{2}{*}{$100 / 45$} & 53 & \multirow{2}{*}{51} \\
\hline $7 \mathrm{~B}$ & & 50 & \\
\hline $8 \mathrm{~A}$ & \multirow{2}{*}{$100 / 55$} & 53 & \multirow{2}{*}{52} \\
\hline $8 \mathrm{~B}$ & & 52 & \\
\hline $9 \mathrm{~A}$ & \multirow{2}{*}{$100 / 65$} & 52 & \multirow{2}{*}{52} \\
\hline 9B & & 52 & \\
\hline $10 \mathrm{~A}$ & \multirow{2}{*}{ 100/75 } & 53 & \multirow{2}{*}{54} \\
\hline 10B & & 55 & \\
\hline $11 \mathrm{~A}$ & \multirow{2}{*}{$100 / 85$} & 56 & \multirow{2}{*}{56} \\
\hline $11 \mathrm{~B}$ & & 57 & \\
\hline CA & \multirow{2}{*}{$0 /-$} & 49 & \multirow{2}{*}{49} \\
\hline CB & & 50 & \\
\hline
\end{tabular}

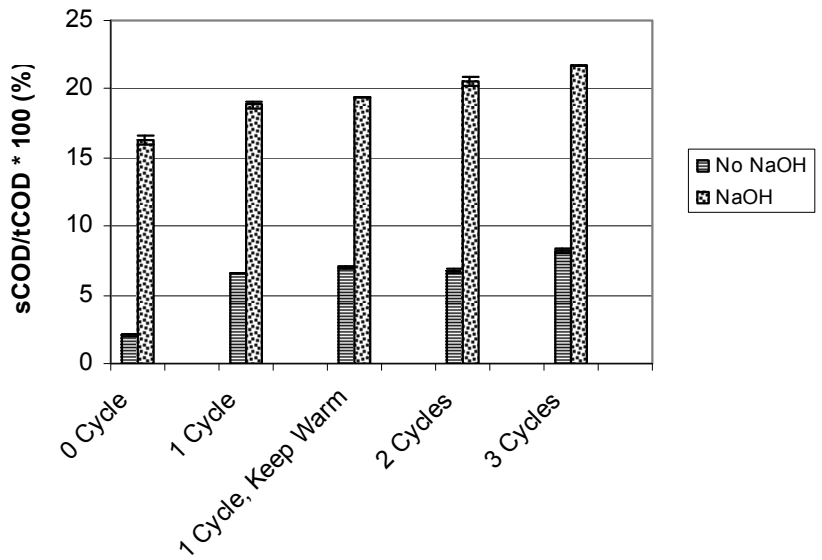

Figure 8

$S C O D / t C O D$ ratio of SBR sludge with multiple $M W$ cycles to $85^{\circ} \mathrm{C}$ with and without alkaline pretreatment

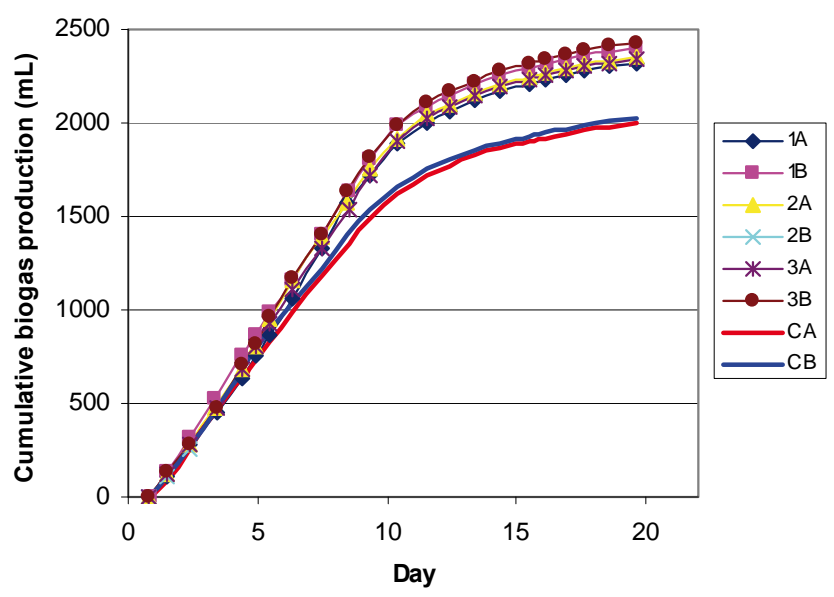

Figure 9

Biogas production of chemically untreated samples $C A / C B$ $1 A / 1 B, 2 A / 2 B, 3 A / 3 B$ irradiated to $85^{\circ} \mathrm{C} 0,1,2$ and 3 times, respectively

sCOD/tCOD ratio increased to $7 \%$ with a single MW cycle and further improvements in COD solubilisation to $8.4 \%$ resulted when irradiating sludge (no alkaline pretreatment) 3 times to $85^{\circ} \mathrm{C}$. Addition of $2 \mathrm{~g} / \ell$ of $\mathrm{NaOH}$ for $12 \mathrm{~h}$ increased the $\mathrm{sCOD} /$ tCOD ratio from $2.06 \pm 0.03$ (control) to $16.3 \pm 0.3 \%$. Combined effects of $\mathrm{NaOH}$ and $\mathrm{MW}$ pretreatment did yield much higher sCOD/tCOD ratios than those obtained by $\mathrm{NaOH}$ pretreatment alone. Additionally, multiple irradiation cycles had a positive effect on the solubilisation of $\mathrm{NaOH}$-treated sludge; the sCOD/ tCOD ratio went from $18.8 \pm 0.3 \%$ when sludge was irradiated once to $21.7 \pm 0 \%$ when it was irradiated 3 times suggesting that a combination of mild chemical and $\mathrm{MW}\left(85^{\circ} \mathrm{C}\right)$ may improve sludge stabilisation over MW or alkaline treatment only. Maintaining sludge at $85^{\circ} \mathrm{C}$ for an additional $10 \mathrm{~min}$ after a single irradiation cycle did not yield appreciable improvements in the solubilisation of COD with or without alkaline pretreatment.

Figure 9 shows cumulative biogas production recorded for alkaline untreated samples irradiated $0,1,2$ and 3 times to $85^{\circ} \mathrm{C}$ and corrected for the contribution of biogas from controls containing only inoculum. Biogas production curves from the control samples are illustrated with smoothed lines to enhance clarity. No lag phase or signs of biomass inhibition were observed. Alkaline untreated samples irradiated 1,2 and 3 times produced similar quantities of biogas with improvement in overall biogas production between 8.7 and $13.9 \%$ over controls. All samples had

an initial maximum biogas production rate of approximately 190 $\mathrm{m} \ell / \mathrm{d}$ lasting from 6 to $11 \mathrm{~d}$. The difference between enhanced biogas production with MW pretreatment and the control was the duration of the initial maximum biogas production rate which was extended from about Day 6 (control) to approximately Day 11 (MW). In general, with the multiple MW pretreatment cycles used $\left(85^{\circ} \mathrm{C}\right)$ there was no improvement in the rate of degradation but there was enhanced substrate degradability over the control. However the variability in the cumulative biogas data does not suggest that multiple $\mathrm{MW}$ cycles to $85^{\circ} \mathrm{C}$ significantly improved the extent of SBR sludge degradation over a single MW cycle.

Cumulative biogas productions recorded for $\mathrm{NaOH}$-treated samples irradiated $0,1,2$ and 3 times to $85^{\circ} \mathrm{C}$ were not significantly different from Fig. 9. Again, no lag phase or signs of biomass inhibition were observed even though the biomass had not been acclimated to $\mathrm{NaOH}$-treated sludge. All $\mathrm{NaOH}$-treated sludge samples irradiated 0, 1, 2 and 3 times produced similar quantities of biogas ranging between 10.3 and $16.8 \%$ greater than the control. The combination of $\mathrm{NaOH}$ and MW pretreatment did not produce any substantially better results in the rate of biogas production or increase in sludge biodegradability over $\mathrm{NaOH}$ pretreatment only or MW pretreatment only. MW pretreatment alone produced similar improvements to $\mathrm{NaOH}$ pretreatment alone or combined $\mathrm{NaOH}$ and $\mathrm{MW}$ pretreatment 


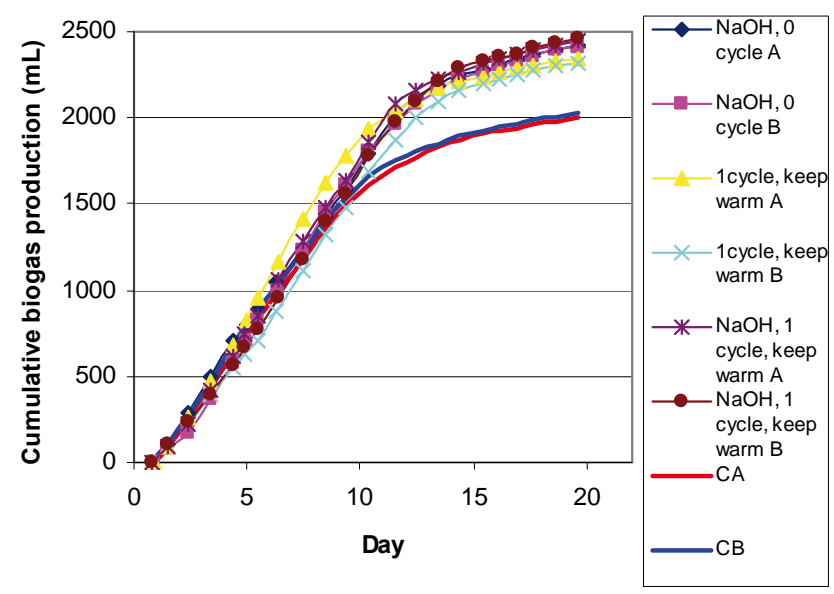

Figure 10

Biogas production of untreated and $\mathrm{NaOH}$-treated SBR sludge with no MW and MW once and maintained at $85^{\circ} \mathrm{C}$ for $10 \mathrm{~min}$

compared to the control and is shown more clearly in Fig. 10. Additionally, multiple irradiation cycles to $85^{\circ} \mathrm{C}$ did not suggest any substantial benefits over a single MW cycle.

Figure 10 shows cumulative biogas production recorded for untreated and $\mathrm{NaOH}$-treated samples irradiated once to a temperature of $85^{\circ} \mathrm{C}$ and maintained at that temperature for an extra $10 \mathrm{~min}$ and corrected for the contribution of biogas from inoculum-only controls. Untreated and $\mathrm{NaOH}$-treated sludge produced similar rates and quantities of biogas. It is interesting to note that $\mathrm{NaOH}$-treated samples that were not heated by MW (sample
4, $\mathrm{NaOH}$ control) produced comparable amounts of biogas to samples that were irradiated. As observed in Figs. 9 and 10, all pretreated samples generated similar amounts of biogas despite different extent of COD solubilisation obtained by varying pretreatments. This may indicate that the pretreatment conditions tested increased the sludge digestibility to a maximum extent. In light of these findings, either a single MW irradiation cycle to $85^{\circ} \mathrm{C}$ on sludge not previously contacted with $\mathrm{NaOH}$ or only mild $\mathrm{NaOH}$ pretreatment may be employed to enhance anaerobic digestibility of Rockland aerobic SBR sludge.

Biogas composition in all tests was 60to 67\% methane and 33 to $40 \% \mathrm{CO}_{2}$. After $20 \mathrm{~d}$ the $\mathrm{pH}$ was recorded to be between 7.5 to 7.7 for all pretreated and control samples while alkalinity ranged between 3400 to $3800 \mathrm{mg} / \ell$ as $\mathrm{CaCO}_{3}$ which are all in an appropriate range for AD. VFAs were less than $10 \mathrm{mg} / \ell$ while sCOD of all samples after digestion ranged between 290 and $470 \mathrm{mg} / \ell$ indicating that a portion of the soluble organic matter was recalcitrant to anaerobic degradation. Additionally, the sCOD concentration was higher than it was at the beginning of the BMP assay which demonstrates that some of the COD that was solubilised by the anaerobic micro-organisms was recalcitrant to degradation. The tCOD removals were consistent with the total biogas production measured (Table 5), as evidenced by the rather consistent methane yield of $0.33 \ell \mathrm{CH}_{4}$ per g COD removed (STP). Average tCOD removal in the controls was $45 \%$ while tCOD removal in all pretreated samples varied between 50 and $54 \%$, a 5 to 9 percentage point improvement. Similarly average VS removals (Table 6) of pretreated samples were as high as $63 \%$, which represents an 11 percentage point improvement over the control. Because similar biogas productions, VS removals

\begin{tabular}{|c|c|c|c|c|c|c|}
\hline \multicolumn{7}{|c|}{$\begin{array}{c}\text { TABLE } 5 \\
\text { Experimental conditions for second BMP assay exposing SBR sludge } \\
\text { to multiple MW cycles }\left(85^{\circ} \mathrm{C}\right) \text { with and without alkaline pretreatment } \\
\text { and effect on tCOD removal and methane yield }\end{array}$} \\
\hline \multirow[b]{2}{*}{ Sample } & \multicolumn{3}{|c|}{ Pretreatment conditions } & \multirow{2}{*}{$\begin{array}{c}\text { tCOD } \\
\text { removal (\%) }\end{array}$} & \multirow{2}{*}{$\begin{array}{l}\text { Average } \\
\text { tCOD re- } \\
\text { moval (\%) }\end{array}$} & \multirow{2}{*}{$\begin{array}{l}\ell \mathrm{CH}_{4} \text { produced } \\
\text { per g COD } \\
\text { removed }(\ell / g)\end{array}$} \\
\hline & $\mathrm{NaOH}$ & $\begin{array}{c}\text { \# of } \\
\text { cycles }\end{array}$ & $\begin{array}{l}\text { Keep } \\
\text { warm }\end{array}$ & & & \\
\hline $1 \mathrm{~A}$ & \multirow{2}{*}{ no } & \multirow{2}{*}{1} & \multirow{2}{*}{ no } & 49 & \multirow{2}{*}{50} & 0.33 \\
\hline $1 \mathrm{~B}$ & & & & 52 & & 0.33 \\
\hline $2 \mathrm{~A}$ & \multirow{2}{*}{ no } & \multirow{2}{*}{2} & \multirow{2}{*}{ no } & 53 & \multirow{2}{*}{53} & 0.31 \\
\hline $2 \mathrm{~B}$ & & & & na & & \\
\hline $3 \mathrm{~A}$ & \multirow{2}{*}{ no } & \multirow{2}{*}{3} & \multirow{2}{*}{ no } & 49 & \multirow{2}{*}{51} & 0.34 \\
\hline 3B & & & & 54 & & 0.33 \\
\hline $4 \mathrm{~A}$ & \multirow{2}{*}{ yes } & \multirow{2}{*}{0} & \multirow{2}{*}{ no } & 54 & \multirow{2}{*}{54} & 0.35 \\
\hline $4 \mathrm{~B}$ & & & & 55 & & 0.35 \\
\hline $5 \mathrm{~A}$ & \multirow{2}{*}{ yes } & \multirow{2}{*}{1} & \multirow{2}{*}{ no } & 50 & \multirow{2}{*}{51} & 0.35 \\
\hline $5 B$ & & & & 52 & & 0.33 \\
\hline $6 \mathrm{~A}$ & \multirow{2}{*}{ yes } & \multirow{2}{*}{2} & \multirow{2}{*}{ no } & 55 & \multirow{2}{*}{53} & 0.32 \\
\hline $6 \mathrm{~B}$ & & & & 50 & & 0.35 \\
\hline $7 \mathrm{~A}$ & \multirow{2}{*}{ yes } & \multirow{2}{*}{3} & \multirow{2}{*}{ no } & 52 & \multirow{2}{*}{53} & 0.34 \\
\hline $7 \mathrm{~B}$ & & & & 54 & & 0.32 \\
\hline $8 \mathrm{~A}$ & n & 1 & voc & 52 & 51 & 0.34 \\
\hline $8 \mathrm{~B}$ & no & 1 & yes & 50 & 51 & 0.34 \\
\hline $9 \mathrm{~A}$ & wO & 1 & 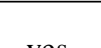 & 52 & 5 & 0.34 \\
\hline $9 B$ & yes & 1 & yes & 53 & 53 & 0.32 \\
\hline CA & & & & 48 & 15 & 0.31 \\
\hline CB & no & 0 & no & 42 & 45 & 0.35 \\
\hline
\end{tabular}




\begin{tabular}{|c|c|c|c|c|c|}
\hline \multicolumn{6}{|c|}{$\begin{array}{c}\text { TABLE } 6 \\
\text { Effect of MW cycles and MW holding time at } 85^{\circ} \mathrm{C} \\
\text { on VS removal (second BMP assay) }\end{array}$} \\
\hline \multirow[b]{2}{*}{ Sample } & \multicolumn{3}{|c|}{ Pretreatment conditions } & \multirow{2}{*}{$\begin{array}{l}\text { VS } \\
\text { removal } \\
(\%)\end{array}$} & \multirow{2}{*}{$\begin{array}{l}\text { Average } \\
\text { VS } \\
\text { removal } \\
(\%)\end{array}$} \\
\hline & $\mathrm{NaOH}$ & $\begin{array}{c}\text { \# of } \\
\text { cycles }\end{array}$ & $\begin{array}{l}\text { Keep } \\
\text { warm }\end{array}$ & & \\
\hline $1 \mathrm{~A}$ & \multirow{2}{*}{ no } & \multirow{2}{*}{1} & \multirow{2}{*}{ no } & 62 & \multirow{2}{*}{60} \\
\hline 1B & & & & 58 & \\
\hline $2 \mathrm{~A}$ & \multirow{2}{*}{ no } & \multirow{2}{*}{2} & \multirow{2}{*}{ no } & 63 & \multirow{2}{*}{63} \\
\hline 2B & & & & na & \\
\hline $3 \mathrm{~A}$ & \multirow{2}{*}{ no } & \multirow{2}{*}{3} & \multirow{2}{*}{ no } & 62 & \multirow{2}{*}{63} \\
\hline 3B & & & & 63 & \\
\hline $4 \mathrm{~A}$ & \multirow{2}{*}{ yes } & \multirow{2}{*}{0} & \multirow{2}{*}{ no } & 65 & \multirow{2}{*}{64} \\
\hline $4 \mathrm{~B}$ & & & & 63 & \\
\hline $5 \mathrm{~A}$ & \multirow{2}{*}{ yes } & \multirow{2}{*}{1} & \multirow{2}{*}{ no } & 68 & \multirow{2}{*}{67} \\
\hline $5 B$ & & & & 66 & \\
\hline $6 \mathrm{~A}$ & \multirow{2}{*}{ yes } & \multirow{2}{*}{2} & \multirow{2}{*}{ no } & 68 & \multirow{2}{*}{64} \\
\hline $6 B$ & & & & 61 & \\
\hline $7 \mathrm{~A}$ & \multirow{2}{*}{ yes } & \multirow{2}{*}{3} & \multirow{2}{*}{ no } & 64 & \multirow{2}{*}{61} \\
\hline $7 \mathrm{~B}$ & & & & 57 & \\
\hline $8 \mathrm{~A}$ & \multirow{2}{*}{ no } & \multirow[b]{2}{*}{1} & Yec & 61 & 61 \\
\hline $8 \mathrm{~B}$ & & & yes & 60 & 01 \\
\hline 9A & vec & 1 & & 64 & 62 \\
\hline 9B & yes & 1 & yes & 61 & 62 \\
\hline CA & n & 0 & no & 50 & 52 \\
\hline CB & 110 & 0 & 110 & 54 & JL \\
\hline
\end{tabular}

and COD removals were obtained for all pretreated samples, the simplest pretreatment option is the most desirable. This would consist of a single MW irradiation cycle of SBR sludge to $85^{\circ} \mathrm{C}$ or mildly alkaline pretreatment without irradiation.

In general all pretreatment methods tested in the second BMP assay produced higher biogas production values. However, all these cases also resulted in an increase in CST indicating a potential deterioration in dewaterability of digested SBR sludge. Based on all CST data gathered no potential improvement in digested SBR sludge dewaterability is anticipated due to MW pretreatment.

\section{Conclusions}

MW irradiation was found to have a positive effect on the anaerobic biodegradability of combined aerobic SBR sludge having a long sludge age. Specifically, with MW temperature attained, MW intensity and sludge concentration were found to have an effect on the maximum sCOD/tCOD ratio achieved which was approximately $7 \%$. However, the most significant parameter was MW pretreatment temperature. Partial MW pretreatment of SBR sludge did not enhance the rate or extent of the anaerobic degradability of SBR sludge. Maximum increase in SBR sludge stabilisation and concomitant increase in biogas production (16.2\%) resulted from $100 \%$ of SBR sludge receiving MW pretreatment to $85^{\circ} \mathrm{C}$. Multiple MW irradiation cycles to $85^{\circ} \mathrm{C}$ did not improve anaerobic degradability of the sludge compared to a single irradiation cycle. Maintaining sludge at $85^{\circ} \mathrm{C}$ for $10 \mathrm{~min}$ after a single irradiation cycle also did not improve the anaerobic degradability of the sludge compared to a single irradiation cycle. Mildly alkaline pretreatment of SBR sludge yielded higher sCOD/tCOD ratios than with MW pretreatment but did not result in increased biodegradability and more biogas production than MW pretreatment. This result suggests that the increased sCOD generated for SBR sludge with long sludge age may in fact be recalcitrant. Improvements in biogas production and tCOD and VS removal were accompanied by a deterioration of sludge dewaterability.

\section{Acknowledgements}

The authors acknowledge the financial support of Environmental Waste International Corporation, National Science and Engineering Council of Canada and BIOCAP Canada.

\section{References}

ABRAHAM K and KEPP U (2003) Commissioning and re-design of a Class A thermal hydrolysis facility for pre-treatment of primary and secondary sludge prior to anaerobic digestion. Proc. WEFTEC $76^{\text {th }}$ Annu. Conf. Exhibit. 8 Oct 2003, Los Angeles, California, USA.

ACKMAN RG (1972) Porous polymer bead packing and formic acid vapour in GLC of volatile fatty acids. J. Chromatogr. Sci. 10 560565.

BARBER WP (2002) Effects of ultrasound on anaerobic digestion of sludge. Proc. $7^{\text {th }}$ Eur. Biosolids and Organic Residuals Conf., Sept 2002, Brighton UK.

BERTHOUEX PM and BROWN LC ( 2002) Statistics for Environmental Engineers. Lewis Publishers, New York.

BROWN JP, CLARK P and HOGAN F (2003) Ultrasonic sludge treatment for enhanced anaerobic digestion at Orange County Sanitation District. Proc. WEFTEC 76 ${ }^{\text {th }}$ Annu. Conf. Exhib. Oct 8, 2003, Los Angeles, California, USA.

DEREIX M, PARKER W and KENNEDY K (2005) Steam-explosion pre-treatment for enhancing anaerobic digestion of municipal wastewater sludge. Proc. WEFTEC 78 ${ }^{\text {th }}$ Annu. Conf. Exhibit. 12 Oct 2005, Washington, DC.

DROSTE RL (1997) Theory and Practice of Water and Wastewater Treatment. John Wiley \& Sons, New York.

ESKICIOGLU C KENNEDY KJ and DROSTE RL (2005) Enhancement of waste activated sludge digestion by microwave pre-treatment. Proc. WEFTEC $78^{\text {th }}$ Annu. Conf. Exhib., 12 Oct 2005, Washington, DC.

GAVALA HN (2003) Mesophilic and thermophilic anaerobic digestion of primary and secondary sludge. Effect of pre-treatment at elevated temperature. Water Res. 37 (19) 4561-4572.

HAUG RT and STUCKEY D C (1978) Effect of thermal pre-treatment on digestibility and dewaterability of organic sludge. J. Water Pollut. Control Fed. 40 73-85.

HONG SM (2002) Enhancement of Pathogen Destruction and Anaerobic Digestibility Using Microwaves. Ph.D. Thesis, Department of Civil and Environmental Engineering, University of WisconsinMadison, USA.

KIM J (2003) Effects of various pre-treatments for enhanced anaerobic digestion with waste activated sludge. J. Biosci. Bioeng. 95 (3) 271275.

LIN JG, CHANG CN and CHANG SC (1997) Enhancement of anaerobic digestion of waste activated sludge by alkaline solubilisation. Biores. Technol. 62 85-90.

MULLER J, WINTER A and STRUNKMANN G (2004) Investigation and assessment of sludge pre-treatment processes. Water Sci. Technol. 49 (10) 97-104.

NAH IW (2000) Mechanical pre-treatment of waste activated sludge for anaerobic digestion process. Water Res. 34 (8) 2362-2368.

PALMOWSKI LM and MULLER JA (2003) Anaerobic degradation of organic materials - Significance of the substrate surface area. Water Sci. Technol. 47 (12) 231-238.

PARK B, HAHN J and HWANG S (2004) Use of microwave pre-treatment for enhanced anaerobiosis of secondary sludge. Water Sci. Technol. 50 (9) 17-23.

SHIN K-S and KANG H (2003) Electron beam pre-treatment of sewage 
sludge before anaerobic digestion. Appl. Biochem. Biotechnol. 109 227-239.

SPEECE RE (1996) Anaerobic Biotechnology for Industrial Wastewaters. Archae Press, Nashville TN, USA.

STANDARD METHODS (1998) Standard Methods for the Examination of Water and Wastewater (19 ${ }^{\text {th }}$ edn.) American Public Health Association, Washington, D.C. United Book Press.

STEPHENSON RJ, LALIBERTÉ S and ELSON P (2004) Use of a highpressure homogenizer to pre-treat municipal biosolids: Introducing the MicroSludge ${ }^{\mathrm{TM}}$ Process. Proc. $10^{\text {th }}$ World Congress on Anaer. Dig. Sept 2004, Montreal, Canada. 1010-1015.

TIEHM A, NICKEL K and NEIS U (2001) Ultrasonic waste activated sludge disintegration for improving anaerobic stabilization. Water Res. 35 (8) 2003-2009.
VAN HUYSSTEEN JJ (1967) Gas chromatographic separation of anaerobic digester gases using porous polymer. Water Res. 1 237-242.

WEEMAES M, GROOTAERD H, SIMOENS $\mathrm{F}$ and VERSTRAETE W (2000) Anaerobic digestion of ozonized biosolids. Water Res. 34 (8) 2330-2336.

WOODWARD SE and WUKASCH RF (1994) A hydrolysis/thickening/ filtration process for the treatment of waste activated sludge. Water Sci. Technol. 30 (3) 29-38.

YEOM IT (2002) Effects of ozone treatment on the biodegradability of sludge from municipal wastewater treatment plants. Water Sci. Technol. 46 (4-5) 421-425.

ZHENG K and KENNEDY KJ (2006) Effect of mild microwave pretreatment on digestion of primary sludge. $41^{\text {st }}$ Central Canadian Symp. Water Qual. Res. 12-15 February, Burlington, ON Canada. 